\title{
ANALISIS KINERJA KETAHANAN PANGAN DI PROVINSI NUSA TENGGARA BARAT (ANALYSIS OF FOOD SECURITY PERFORMANCEIN WEST NUSA TENGGARA)
}

\author{
Enirawan', Setia Hadi², Bambang Juanda ${ }^{2}$, Ernan Rustiadi ${ }^{2}$ \\ ${ }^{1}$ Mahasiswa dan ${ }^{2}$ Dosen Sekolah Pascasarjana Program Studi Ilmu Perencanaan \\ Pembangunan Wilayah dan Perdesaan (PWD)-IPB
}

\section{E-mail : enirawan@yahoo.com}

\begin{abstract}
ABSTRAK. Isu ketahanan pangan di Provinsi Nusa Tenggara Barat (NTB) yakni ketersediaan pangan yang memadai di tingkat wilayah, namun merupakan daerah rentan pangan. Penelitian ini menggunakan analisis deskriptif ketahanan pangan dan analisis regresi. Kinerja ketahanan pangan pada aspek ketersediaan adalah surplus, namun pada aspek distribusi belum stabil sedangkan aspek konsumsi ditandai masih tingginya persentase penduduk miskin dan rasio kasus gizi buruk per 1000 penduduk walau dengan trend menurun. Untuk meningkatkan ketahanan pangan wilayah di Provinsi NTB maka perlu upaya peningkatan produktivitas lahan pertanian, peningkatan akses lembaga keuangan, peningkatan peran koperasi dalam mendukung kegiatan usaha tani dan distribusi pangan, Pendidikan masyarakat serta pengembangan pelayanan kesehatan di Provinsi NTB

Kata Kunci : ketahanan pangan, Ketersediaan pangan, distribusi, penduduk miskin, gizi buruk
\end{abstract}

\section{PERFORMANCE ANALYSIS OF FOOD SECURITY IN WEST NUSA TENGGARA (ANALYSIS OF FOOD SECURITY WEST NUSA TENGGARA PERFORMANCEIN )}

\begin{abstract}
The issues of food security in NTB Province include the adequate food supply at the regional level and the areas vulnerable to a food shortage. This study used a descriptive analysis of food security and regression analysis. In terms of availability, the performance of food security shows a surplus although the distribution aspect is not yet stable. The consumption aspect is still marked by the high percentage of the poor and the ratio of malnutrition cases per 1000 people. However, there is a downward trend. To increase the level of food security in NTB province, there should be concrete measures to improve agricultural productivity, access to financial institutions, the role of cooperatives in supporting farming and food distribution, community education, and the development of health services in NTB.
\end{abstract}

Keywords: food security, food availability, distribution, poor people, malnutrition.

\section{PENDAHULUAN}

Ketahanan Pangan adalah kondisi terpenuhinya Pangan bagi negara sampai dengan perseorangan, yang tercermin dari tersedianya Pangan yang cukup, baikjumlah maupun mutunya, aman, beragam, bergizi, merata, dan terjangkau serta tidak bertentangan dengan agama, keyakinan, dan budaya masyarakat, untuk dapat hidup sehat, aktif, dan produktif secara berkelanjutan (Undang-Undang Republik Indonesia Nomor 18 Tahun 2012 Tentang Pangan).

Ketahanan pangan merupakan suatu sistem ekonomi pangan yang terintegrasi yang terdiri atas berbagai subsistem. Subsistem utamanya adalah ketersediaan pangan, distribusi pangan, dan konsumsi pangan. Temuan utama FSVA (2009) di Indonesia adalah pada sisi ketersediaan, hasil pertanian meningkat. Laju peningkatan sekitar $3.5 \%$ pertahun selama 2004-2007 dan mencapai 4.8\% pada tahun 2008. Produksi padi dan jagung meningkat, walaupun produksi ubi kayu dan ubi jalar relatif stabil, sedangkan produksi kacang kedelai dan kacang tanah menurun.

Pada umumnya, mayoritas daerah di Indonesia merupakan daerah swasembada/ surplus pangan dalam hal serelia, dan ketersediaan pangan pada tingkat nasional memadai. Sementara gambaran pemanfaatan pangan dan status gizi dapat dilihat pada rata-rata asupan energy harian adalah 2,050 kkal dan asupan protein sebesar 56,25 gram, keduanya sudah melampaui angka kecukupan gizi (AKG) nasional. Angka ini meningkat 3,3\% dibandingkan tahun 2002.
Namun demikian, untuk tiga golongan pengeluaran terendah hanya memiliki asupan 1,817 kkal/kapita/ hari atau kurang, dan proporsi makanan mereka kurang serta tidak seimbang secara kuantitatif dan kualitatif.

Provinsi NTB merupakan daerah surplus pangan yang diindikasikan dengan nilai produksi pangan padi yang surplus dan ketersediaan pangan tumbuhan dan hewani lainnya yang cenderung meningkat, namun data menunjukkan beberapa daerah di NTB termasuk 100 kabupaten di Indonesia yang memiliki tingkat resiko kerentanan tinggi dan memerlukan skala prioritas penanganan, yakni sebanyak 70,83\% dari jumlah kecamatan di Provinsi NTB merupakan wilayah yang rentan pangan (FSVA, 2009 dan Pemda NTB, 2010).

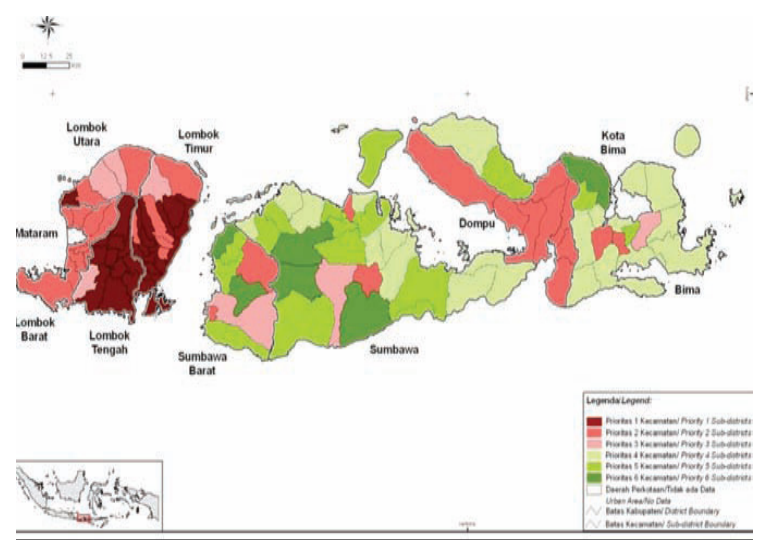

Gambar 1. Peta Ketahanan dan Kerentanan Pangan Provinsi NTB Tahun 2010 (Sumber : FSVA NTB, 2010) 
Isu ketahanan pangan di Provinsi NTB yakni ketersediaan pangan yang memadai di tingkat wilayah merupakan faktor penting, namun belum cukup memadai untuk menjamin konsumsi pangan khususnya pada kelompok rumah tangga dan individu berpendapatan rendah (miskin). Menurut Ariani, et al., (2007) ketahanan pangan di suatu wilayah mempunyai sifat multidimensional yang ditentukan oleh berbagai faktor serta melibatkan berbagai sektor. Mengacu pada karakteristik yang beragam tersebut, maka pemecahan masalah ketahanan pangan wilayah harus bersifat holistik dengan memperhatikan faktor-faktor yang mempengaruhinya.

Berdasarkan uraian di atas maka yang menjadi pertanyaan penelitian adalah bagaimana kinerja ketahanan pangan dan faktor-faktor apa saja yang menentukan kinerja ketahanan pangan di Provinsi Nusa Tenggara Barat?. Adapun yang menjadi tujuan penelitian adalah : Menganalisis kinerja ketahanan pangan dan faktor-faktor yang mempengaruhi kinerja ketahanan pangan tingkat wilayah di Provinsi Nusa Tenggara Barat.

\section{METODE}

Penelitian menggunakan data sekunder yang berasal dari BPS Kabupaten dan Provinsi Lingkup Provinsi Nusa Tenggara Barat tahun 2003-2012. Untuk mengukur kinerja ketahanan pangan maka digunakan analisis deskriptif. Untuk menganalisis faktor-faktor yang mempengaruhi

ketahanan pangan tersebut digunakan analisis regresi.

\section{HASIL DAN PEMBAHASAN Kinerja Ketahanan Pangan}

Kinerja ketahanan pangan dianalisis pada tiga aspek yakni aspek ketersediaan, distribusi dan konsumsi pangan. Aspek ketersediaan ketahanan pangan yaitu tersediaanya pangan untuk memenuhi kebutuhan seluruh penduduk baik jumlah maupun mutunya serta aman. Dalam penelitian ini aspek ketersediaan pangan tingkat wilayah diproksi dari rasio produksi padi terhadap kebutuhan normatif. Jika menggunakan kriteria Purwantini, et al., (2006) yakni indeks $>1,2$ = surplus (termasuk cadangan $20 \%$ ), maka tingkat ketersedian pangan padi di NTB adalah rata-rata surplus, yakni dengan nilai indeks ratarata sebesar 2,91 (tahun 2012).

Tingkat ketersediaan pangan beras menunjukkan trend positif sebagai terlihat pada gambar 2. rata-rata indeks tingkat ketersediaan pangan beras meningkat sebesar 0,084 pertahun. Hal ini sebagai indikasi peningkatan kemandirian pangan yakni melalui peningkatan ketahanan pangan yang berbasiskan sumber daya lokal.

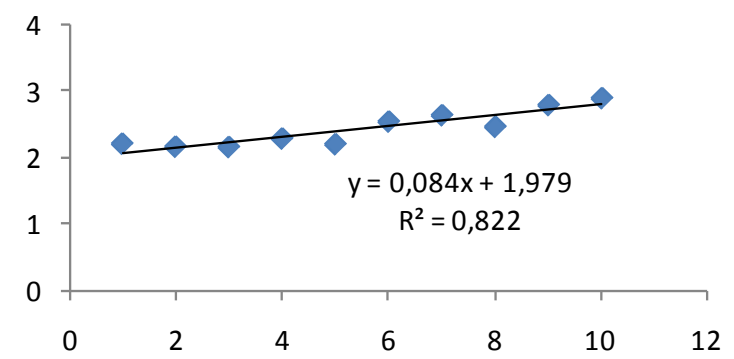

Gambar 2. Rata-Rata Tingkat Ketersediaan Pangan Padi di Provinsi NTB Tahun 2003-2012 (Sumber : Data BPS Kabupaten dan Provinsi NTB Tahun 2004-2013 yang diolah)
Aspek distribusi ketahanan pangan adalah kondisi pasokan pangan yang dapat menjangkau ke seluruh wilayah sehingga harga pangan stabil dan terjangkau oleh rumah tangga.

Indikator stabilitas harga dapat diproksi menggunakan koefisien variasi (KV) yang merupakan nilai standar deviasi yang distandarisasikan dengan harga rata-rata (rasio standar deviasi terhadap harga rata-rata). Jika nilai koefisien variasi semakin rendah menunjukkan harga makin stabil. Rata-rata nilai koefisien variasi (KV) pangan beras di Provinsi NTB tahun 2012 adalah sebesar 0.05 . Nilai koefisien variasi (KV) pangan beras di Provinsi NTB beragam antar daerah. Dalam konteks ketahanan pangan, faktor ketersediaan (food availability) dan aksesibilitas (food accessibility) pangan merupakan dua faktor penting dalam peningkatan ketahanan pangan rumah tangga (Saliem, et al. 2006).

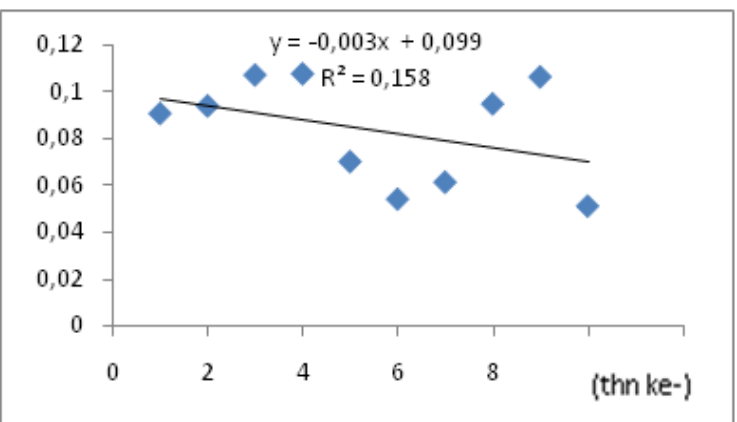

Gambar 3. Rata-Rata Koefisien Variasi Harga Pangan Beras di Provinsi NTB Tahun 2003-2012 (Sumber : Data BPS Kabupaten dan Provinsi NTB Tahun 2004-2013 yang diolah)

Koefisien variasi harga pangan beras sangat bervariasi dan berfluktuasi namun menunjukkan trend negatif yang bermakna pergerakan harga antar waktu (bulan) semakin stabil sebagai terlihat pada gambar 3. rata-rata nilai koefisien variasi harga pangan beras menurun sebesar 0,003 pertahun. Hal ini sebagai indikasi kualitas distribusi pangan beras yang semakin baik.

Aspek konsumsi dianalisis dengan indikator persentase penduduk miskin dan kasus gizi buruk per 1000 penduduk. Persentase penduduk miskin merupakan rasio jumlah penduduk miskin terhadap jumlah penduduk di suatu wilayah. Penduduk miskin merupakan penduduk yang memiliki pendapatan/ pengeluaran di bawah garis kemiskinan, sehingga indikator kemiskinan menggambarkan kemampuan ekonomi penduduk untuk mendapatkan pangan yang cukup dan berkelanjutan (akses ekonomi).

Persentase penduduk miskin di NTB dengan rata-rata nilai $18.17 \%$ dan cenderung mengalami penurunan sebagaimana terlihat pada gambar 4 . Rata-rata persentase penduduk miskin di Provinsi NTB menurun sebesar 0,83 pertahun. Kondisi ini menjelaskan bahwa pendapatan atau pengeluaran penduduk semakin meningkat sehingga dapat meningkatkan konsumsi pangan yang memadai yang selanjutnya dapat meningkatkan ketahanan pangan penduduk. 


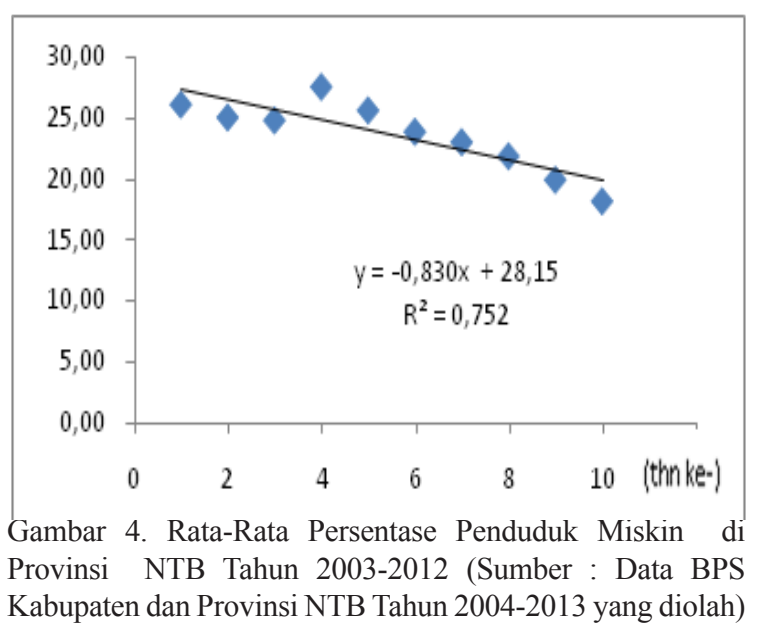

Gizi buruk adalah keadaan kekurangan energi dan protein tingkat berat akibat kurang mengkonsumsi makanan yang bergizi dan atau menderita sakit dalam waktu lama. Status gizi mencerminkan kondisi ketahanan pangan pada aspek konsumsi. Dalam penelitian ini status gizi buruk distandarisasikan dengan jumlah penduduk yang dihitung dengan rasio kasus gizi buruk per 1000 penduduk, semakin tinggi nilai rasio kasus gizi buruk per 1000 penduduk maka semakin banyak penduduk yang mengalami kekurangan energi dan protein tingkat berat. Ratarata rasio kasus gizi buruk per 1000 penduduk di NTB adalah sebanyak 0,20 yang bermakna setiap 1000 penduduk terdapat 0,20 kasus atau terdapat 1 kasus dalam populasi sebanyak 5000 penduduk.

Rata-rata rasio kasus gizi buruk per 1000 penduduk di Provinsi NTB menunjukkan trend negatif walaupun sempat terjadi kenaikan pada tahun 2009-2010 namun kembali menurun pada tahun 2011-2012 sebagai terlihat pada gambar 5. Ratarata nilai rasio kasus gizi buruk per 1000 penduduk menurun sebesar 0,015 pertahun. Hal ini sebagai indikasi semakin membaiknya status gizi dan tingkat ketahanan pangan di Provinsi NTB.

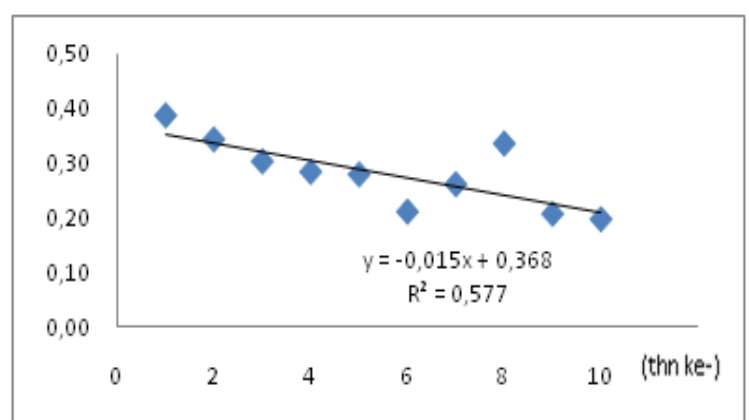

Gambar 5. Rata-Rata Rasio Kasus Gizi Buruk Per 1000 Penduduk di Provinsi NTB Tahun 2003-2012 (Sumber : Data BPS Kabupaten dan Provinsi NTB Tahun 2004-2013 yang diolah)

Hasil analisis deskriptif dan trend menunjukkan kinerja ketahanan pangan yang semakin baik, namun pola tiga aspek ketahanan pangan relatif berbeda yang menunjukkan bahwa kinerja setiap aspek ketahanan pangan bukan ditentukan secara tunggal oleh aspek ketahanan pangan lainnya, namun ditentukan juga oleh faktor lainnya.
Ketersediaan pangan dan akses terhadap pangan (dimensi fisik dan ekonomi) merupakan determinan penting dari ketahanan pangan (Braun, et al., 1992). Maxwell (1996) menyampaikan elemen ketahanan pangan berkelanjutan (sustainable food security), antara lain: (1) kecukupan pangan, merupakan jumlah kalori yang dibutuhkan untuk kehidupan yang aktif dan sehat; (2) akses atas pangan, yakni sebagai hak (entitlements) untuk berproduksi, membeli atau menukarkan (exchange) pangan ataupun menerima sebagai pemberian (transfer).

Faktor-Faktor Yang Mempengaruhi Kinerja Ketahanan Pangan Wilayah

1. Faktor-Faktor Yang Mempengaruhi Aspek Ketersediaan/Produksi Pangan

Untuk mengetahui pengaruh berbagai faktor terhadap tingkat ketersediaan pangan maka dilakukan analisis regresi seperti pada Tabel 1. Persamaan regresi tersebut memiliki nilai $\mathrm{F}=4382$ dengan tingkat signifikan pada $\alpha=5 \%$ yang menunjukkan model regresi tersebut dapat menjelaskan keragaman tingkat ketersediaan pangan beras di Provinsi NTB.

Hasil analisis regresi juga menjelaskan peningkatan ketersediaan pangan padi dipengaruhi secara signifikan oleh peningkatan luas panen padi/kapita dengan koefisien regresi sebesar 27,22 (signifikan pada $\alpha=5 \%$ ), yang bermakna bahwa peningkatan luas panen padi/kapita sebesar $0,1 \mathrm{Ha} /$ Jiwa dapat mendorong peningkatan rata-rata ketersediaan pangan padi sebesar 2,72 (dengan asumsi variabel lain konstan).

Tabel 1. Koefisien Persamaan Tingkat ketersediaan pangan padi di NTB

\begin{tabular}{ccccc}
\hline $\begin{array}{c}\text { Y=Tk ketersediaan } \\
\text { pangan beras (indeks) }\end{array}$ & \multicolumn{2}{c}{$\begin{array}{c}\text { Unstandardized } \\
\text { Coefficients }\end{array}$} & T & Sig. \\
\hline $\begin{array}{c}\text { (Constant) } \\
\text { Buas Panen/Kapita } \\
\text { (Ha/jiwa) }\end{array}$ & -2.748 & .145 & -19.02 & .000 \\
$\begin{array}{c}\text { Std. Error } \\
\text { Produktivitas padi (ton/Ha) }\end{array}$ & .596 & .031 & 19.1 & .000 \\
$\begin{array}{c}\text { Tk Pelayanan BPR (ribu } \\
\text { penduduk/unit BPR) } \\
\text { Tk pelayanan Jalan } \\
\text { berkualitas (Jiwa/km) }\end{array}$ & .000 & .000 & -1.07 & .287 \\
\hline
\end{tabular}

Daerah-daerah di Pulau Sumbawa (kecuali Kota Bima) memiliki potensi lahan pertanian yang luas yang ditunjukkan dengan nilai Luas panen padi/ kapita (ha/jiwa) yang relatif tinggi. Sebagai contoh luas panen padi/kapita di Kabupaten Sumbawa pada tahun 2012 adalah sebesar 0,20 ha/jiwa, sedangkan daerah-daerah di Pulau Lombok pada umum memiliki luas panen padi/kapita $<0,10$ Ha. Namun luas panen padi/kapita daerah-daerah di NTB pada umumnya memiliki trend nilai yang meningkat.

Tingkat ketersediaan pangan beras juga didukung oleh nilai produktivitas padi (ton/Ha). Hasil analisis regresi memberikan nilai koefisien regresi sebesar 0,596, yang bermakna jika variabel lain dianggap tetap maka peningkatan produktivitas padi sebesar 1 ton/Ha akan meningkatkan 0,596 rata-rata indeks ketersediaan pangan padi. Nilai produktivitas padi 
di Provinsi NTB Tahun 2009-2012 berkisar antara 4,33-5,48 ton/Ha,

IFPRI (2011) manyampaikan untuk meningkatkan ketahanan pangan perlu stimulasi pertumbuhan pertanian dan pada khususnya, pertumbuhan pertanian yang secara langsung dapat memberikan manfaat bagi penduduk miskin. Hossain, et al (2005) melakukan penelitian di Bangladesh dan menjelaskan ketahanan pangan bersinonim dengan pencapaian swasembada produksi beras. Nurmalina $(2007,2008)$, menjelaskan terdapat tiga faktor yang mempunyai pengaruh kuat juga ketergantungan kuat antar faktor yaitu produksi, produktivitas dan konsumsi perkapita

Untuk meningkatkan ketersediaan pangan maka dibutuhkan dukungan pembiayaan dalam melaksanakan kegiatan usaha tani. Berbagai lembaga keuangan (baik formal maupun lembaga keuangan tradisional) dapat berperan dalam pembiayaan usaha tani. Adapun indikator tingkat layanan lembaga keuangan di suatu wilayah dapat dilihat dari nilai rasio jumlah penduduk yang dilayani setiap satu BPR (ribu penduduk /unit BPR), makin tinggi nilai rasio jumlah penduduk yang dilayani perunit BPR menunjukkan makin rendah tingkat pelayanan BPR tersebut. Nazam (2011) menjelaskan salah satu faktor penghubung (leverage faktors), dalam keberlajutan produksi (ketersediaan) beras (pangan) adalah ketersediaan modal bagi pembiayaan usaha masyarakat tani. Namun hasil analisis regresi menunjukkan tingkat pelayanan BPR belum berpengaruh signifikan yang bermakna BPR masih rendah dalam mendukung kegiatan usaha tani dan peningkatan ketersediaan pangan di Provinsi NTB.

Aksesibilitas fisik juga berpengaruh terhadap peningkatan ketersediaan pangan padi, hal ini dapat ditunjukkan dari koefisien regresi variabel tingkat pelayanan jalan berkualitas (Jiwa/km) yakni sebesar $-3,66 \mathrm{E}-5$. yang bermakna bahwa peningkatan kualitas infrastruktur trasportasi yang ditunjukkan dengan penurunan koefisien regresi dari rasio jumlah penduduk yang mendapat layanan setiap satu $\mathrm{km}$ infrastruktur transportasi berkualitas dapat meningkatkan ketersediaan pangan padi, karena peningkatan akses jalan akan menurunkan biaya transportasi dan memudahkan penduduk untuk menjangkau lahan pertanian sehingga menjadi insentif bagi penduduk untuk meningkatkan produksi pertanian baik melalui intensifikasi maupun dengan ekstensifikasi seperti dengan membuka lahan pertanian pada lahan-lahan tidur. Socha, et al. (2012) menjelaskan bahwa Ketahanan pangan terjadi ketika penduduk memiliki akses fisik terhadap pangan yang mencukupi, aman dan bergizi dalam memenuhi kebutuhan dan preferensi pangannya untuk kehidupan yang aktif dan sehat. sedangkan Adenew (2004) menyatakan bahwa untuk mencapai tujuan peningkatan ketahanan pangan nasional, adalah perlu untuk memperbaiki investasi pada infrastruktur yang dapat menurunkan biaya transaksi pangan, menyediakan insentif untuk peningkatan produksi.

\section{Faktor-Faktor Yang Mempengaruhi Aspek Distribusi Pangan}

Suryana (2003) menjelaskan untuk mewujudkan ketahanan pangan antara lain terpenuhinya pangan dengan kondisi yang merata. Subsistem distribusi bukan semata-mata mencakup aspek fisik dalam arti pangan yang tersedia di semua lokasi yang membutuhkan, tetapi juga menyangkut keterjangkauan ekonomi antara lain dicerminkan oleh harga yang stabil.

Untuk mengetahui pengaruh berbagai faktor terhadap Nilai Koefisien Variasi (KV) Harga Beras sebagai indikator aspek distribusi maka dilakukan analisis regresi dengan hasil pada Tabel 2.

Tabel 2. Koefisien Persamaan Koefisien Variasi (KV) Harga Beras di NTB

\begin{tabular}{ccccc}
\hline $\begin{array}{c}\text { Y= koefisien variasi harga pangan } \\
\text { beras }\end{array}$ & \multicolumn{2}{c}{$\begin{array}{c}\text { Unstandardized } \\
\text { Coefficients }\end{array}$} & $\mathrm{T}$ & Sig. \\
& $\mathrm{B}$ & Std. Error & & \\
\hline $\begin{array}{c}\text { (Constant) } \\
\text { Tk pelayanan koperasi (jiwa/unit } \\
\text { koperasi) }\end{array}$ & .077 & .012 & 6.4 & .000 \\
$\begin{array}{c}\text { Ketersediaan Jalan berkualitas (km) } \\
\text { Tk ketersediaan beras (indeks) }\end{array}$ & $-2.4 \mathrm{E}-7$ & .000 & -.01 & .991 \\
\hline
\end{tabular}

Persamaan regresi di atas memiliki nilai $\mathrm{F}=4,99$ dengan tingkat signifikan pada $\alpha=5 \%$ yang menunjukkan model regresi tersebut dapat menjelaskan keragaman nilai koefisien variasi harga pangan beras di Provinsi NTB.

Tingkat ketersediaan pangan beras dalam wilayah berpengaruh sinifikan ( $\alpha=15 \%)$ dengan nilai kofisien sebesar -0,005, yang menunjukkan peningkatan ketersediaan pangan beras dalam wilayah dapat meningkatan stabilitas harga sehingga upaya peningkatan kemadirian pangan dapat meningkatkan stabilitas ekonomi baik tingkat lokal, regional maupun nasional.

Akses ekonomi diindikasi dengan tingkat pelayanan koperasi (jiwa/unit koperasi). Makin rendah rasio jumlah penduduk yang mendapat layanan setiap satu unit koperasi maka hal ini menunjukkan makin tinggi akses ekonomi di wilayah tersebut. Hasil analisis regresi menunjukkan rasio jumlah penduduk yang mendapat layanan setiap satu unit koperasi (jiwa penduduk/unit koperasi) memiliki koefisien regresi dengan tanda positif terhadap Koefisien Variasi Harga Pangan Beras di Provinsi NTB, yang bermakna peningkatan akses ekonomi dan ketersediaan lembaga distribusi pangan dapat meningkatkan stabilitas harga pangan.

Pengaruh aksesibilitas fisik/transportasi terhadap stabilitas harga dapat dilihat dari ketersediaan jalan berkualitas. Dengan koefisien -2,4e-7, yang menunjukkan peningkatan ketersediaan jalan berkualitas dapat menurunkan fluktuasi harga, namun hasil analisis regresi menunjukkan pengaruhnya tidak signifikan. Hal ini semakin memperkuat penjelasan di atas, bahwa jika ketersediaan transportasi jalan yang berkualitas sudah relatif merata dan terjangkau, maka yang menentukkan tingkat stabilitas harga adalah 
tingkat ketersediaan dan dinamika kelembagaan pangan khususnya kelembagaan distribusi pangan. Kondisi ini menunjukkan bahwa ketersediaan aksesibilitas fisik di wilayah tersebut belum didukung oleh kegiatan ekonomi dan distribusi pangan secara memadai karena rendahnya ketersediaan kelembagaan distribusi yang dapat menjangkau dan dijangkau oleh penduduk khususnya penduduk yang berpendapatan rendah (kelompok miskin).

Penjelasan di atas searah dengan hasil penelitian Adenew (2004) dan Nissanke (2011) bahwa untuk mencapai tujuan peningkatan ketahanan pangan nasional, adalah perlu untuk memperbaiki fungsi pasar, investasi pada infrastruktur yang dapat menurunkan biaya transaksi pangan serta pencapaian swasembada produksi beras dan stabilisasi harga beras (Hossain, et al., 2005). Kedaulatan pangan lahir dari meningkatnya akses terhadap sistem pangan. pengembangan pertanian dalam arti luas, dan koperasi masyarakat (Socha, et al., 2012)

\section{3a. Faktor-Faktor Yang Mempengaruhi Aspek Konsumsi Pangan : Persentase Penduduk Miskin}

Secara agregat konsumsi energi dan protein semakin tinggi dengan meningkatnya kelas pendapatan rumah tangga. Keterbatasan penguasaan bahan pangan secara fisik, sosial-ekonomi dan tekanan kenaikan harga membuat petani (masyarakat miskin) cenderung mengubah pola konsumsi (Saliem, et al. 2006)

Untuk mengetahui pengaruh berbagai faktor terhadap persentase penduduk miskin maka dilakukan análisis regresi dengan hasil pada Tabel 3. Dari hasil analisis regresi diketahui bahwa persamaan regresi di atas memiliki nilai $\mathrm{F}=45,336$ dengan tingkat signifikan pada $\alpha=5 \%$ yang bermakna model regresi tersebut dapat menjelaskan keragaman nilai Persentase Penduduk Miskin di Provinsi NTB. Persentase penduduk miskin dipengaruhi oleh tingkat pelayanan lembaga keuangan, ketersediaan infrastruktur berkualitas, tingkat pendidikan, dan harga pangan beras, namun variabel rata-rata harga berpengaruh tidak signifikan.

Tabel 3. Koefisien Persamaan Persentase Penduduk Miskin di NTB

\begin{tabular}{|c|c|c|c|c|}
\hline \multirow{3}{*}{$\begin{array}{l}Y=\text { Persentase Jumlah } \\
\text { Penduduk Miskin (\%) }\end{array}$} & \multicolumn{2}{|c|}{ Unstandardized } & \multirow{3}{*}{$\mathrm{T}$} & \multirow{3}{*}{ Sig. } \\
\hline & \multicolumn{2}{|c|}{ Coefficients } & & \\
\hline & B & Std. Error & & \\
\hline (Constant) & 61.026 & 4.52 & 13.5 & .000 \\
\hline $\begin{array}{c}\text { Tingkat Pelayanan Bank (Ribu } \\
\text { penduduk/unit bank) }\end{array}$ & .035 & .010 & 3.6 & .001 \\
\hline $\begin{array}{l}\text { keters ediaan infrastruktur } \\
\text { berkualitas }(\mathrm{km})\end{array}$ & -.010 & .003 & -3.9 & .000 \\
\hline $\begin{array}{l}\text { Lama pendidikan penduduk } \\
\text { laki-laki (tahun) }\end{array}$ & -5.191 & .550 & -9.4 & .000 \\
\hline Rata-rata harga beras (Rp.) & .000 & .000 & .86 & .390 \\
\hline
\end{tabular}

Tingkat pelayanan bank dapat ditunjukkan dengan rasio jumlah penduduk yang mendapat layanan setiap satu unit bank (Ribu penduduk/unit bank). Rasio jumlah penduduk yang mendapat layanan setiap satu unit bank (tingkat pelayanan bank yang rendah) berpengaruh positif terhadap persentase penduduk miskin di Provinsi NTB, dengan koefisien sebesar 0,035 yang bermakna bahwa setiap peningkatan ketersediaan bank sehingga berkurang 100.000 penduduk yang dilayanani oleh setiap unit bank akan menurunkan penduduk miskin sebesar 3,5\%, Hal ini sebagai indikasi bahwa pengembangaan ekonomi riil khususnya pada kegiatan ekonomi mikro, skala kecil dan menengah membutuhkan dukungan kelembagaan keuangan, antara lain melalui skim kredit usaha rakyat, kredit lunak serta melalui fasilitasi kepastian kepemilikan asset (sertifikasi) agar masyarakat memiliki agunan kredit perbankan sebagai syarat adanya jaminan (kolateral) perbankan, karena kelompok berpendapatan rendah relatif memiliki keterbatasan asset yang dapat diakui sebagai jaminan perbankan. Kedua, skim kredit perbankan relatif terbatas untuk pengembangan usaha mikro, kecil dan menengah yang merupakan sektor ekonomi bagi kelompok berpendapatan rendah.

Ketersediaan infrastruktur berkualitas memiliki koefisien regresi sebesar $-0,10$ yang bermakna setiap peningkatan ketersediaan $10 \mathrm{~km}$ jalan yang berkualitas maka secara rata-rata penduduk miskin menurun sebesar 1,00 persen. Selain itu variabel lama pendidikan penduduk (laki-laki) juga memiliki hubungan negatif dengan persentase penduduk miskin dengan nilai koefisien regresi sebesar -5.19, yang bermakna setiap kenaikan lama pendidikan sebesar satu tahun dapat menurunkan rata-rata penduduk miskin sebesar 5.19 persen. Hal ini disebabkan dengan peningkatan pendidikan maka dapat meningkatkan peluang mendapatkan pekerjaan, peningkatan, produktivitas dan pendapatan penduduk yang pada akhirnya dapat menurunkan persentase penduduk miskin.

Kemiskinan di Indonesia dalam kondisi kurangnya kesempatan (lack of opportunity) dan rendahnya kemampuan (low af capabilities) (Yudhoyono dan Harniati , 2004). Ikhsan (2001) menunjukkan beberapa determinan kemiskinan di daerah pedesaan yaitu: (1) human capital endowment yang belum memadai yang menyulitkan proses transformasi tenaga kerja antar sektor, (2) kuantitas dan kualitas infrastuktur, (3) faktor yang berkaitan dengan kebijakan pemerintah.

Penduduk miskin merupakan kelompok rentan terhadap kerawanan pangan sehingga dibutuhkan investasi di daerah/penduduk miskin (Committee on World Food Security, 2012), membutuhkan struktur institusi termasuk aturan dan organisasi yang dapat menyampaikan layanan sampai pedesaan, mendukung tindakan kolektif, dan memperkuat hakhak properti penduduk miskin dan akses terhadap asset (IFPRI, 2011), organisasi ini harus membangun jejaring hubungan yang erat antar pelaku pasar khususnya di perdesaan dan pengambil kebijakan (Herbel, et al., 2012).

\section{3b. Faktor-Faktor Yang Mempengaruhi Aspek Konsumsi Pangan : Status Gizi Buruk}

Kasus Gizi Buruk antara lain dapat dipengaruhi oleh tingkat produktivitas pangan, tingkat aksesibilitas 
fisik dan tingkat pelayanan kesehatan (Pemerintah Provinsi NTB, 2010 dan Irawan, 2004). Untuk mengetahui pengaruh berbagai faktor Rasio Kasus Gizi Buruk Per 1000 Penduduk maka dilakukan analisis regresi dengan hasil pada Table 4. Dari hasil analisis regresi diketahui bahwa persamaan regresi di atas memiliki nilai $\mathrm{F}=19,23$ dengan tingkat signifikan pada $\alpha=5 \%$ yang menunjukkan model regresi tersebut dapat menjelaskan keragaman nilai rasio kasus gizi buruk per 1000 penduduk di Provinsi NTB.

Berdasarkan hasil analisis regresi, Tingkat Produktivitas pangan padi berpengaruh terhadap Kasus Gizi Buruk per 1000 penduduk dengan koefisien regresi sebesar -0,100, yang bermakna setiap peningkatan produktivitas pangan padi satu Ton/Ha akan dapat menurunkan rata-rata 0,100 Kasus Gizi Buruk per 1000 penduduk dengan asumsi variabel lain tetap. Rata-rata produktivitas di NTB tahun 2012 adalah berkisar 4,705,34 ton/Ha.

Tabel 4-5.8. Koefisien Persamaan Rasio Kasus Gizi Buruk Per1000 Penduduk di NTB

\begin{tabular}{ccccc}
\hline \multirow{2}{*}{$\begin{array}{c}\text { Y }=\text { Rasio Kasus Gizi Buruk/1000 } \\
\text { Pddk }\end{array}$} & \multicolumn{2}{c}{ Coefficients } & T & Sig. \\
& B & SE & & \\
\hline (Constant) & 0,585 & 0,198 & 2,95 & 0,004 \\
$\begin{array}{c}\text { Produktivitas pangan padi (Ton/Ha) } \\
\text { Tk pelayanan prasarana jalan }\left(\mathrm{km}^{2}\right. \\
\text { wilayah/kmjalan berkualitas) }\end{array}$ & $-0,1$ & 0,042 & $-2,4$ & 0,018 \\
$\begin{array}{c}\text { Tk pelayanan rumah sakit (jiwa/unit } \\
\text { RS) }\end{array}$ & $2,30 \mathrm{E}-07$ & 0 & 3,34 & 0,001 \\
\hline
\end{tabular}

Rasio luas wilayah yang mendapat layanan setiap satu kilo meter infrastruktur transportasi berkualitas menunjukkan tingkat aksesibilitas fisik wilayah. Semakin tinggi Rasio luas wilayah yang mendapat layanan setiap satu kilo meter infrastruktur transportasi berkualitas menunjukkan semakin rendah aksesibilitas fisik wilayah.

Rasio luas wilayah yang mendapat layanan setiap satu kilo meter infrastruktur transportasi berkualitas memiliki koefisien regresi sebesar 0,012 yang bermakna setiap peningkatan luas wilayah $1 \mathrm{~km}^{2}$ yang mendapat layanan setiap satu kilo meter infrastruktur transportasi berkualitas (penurunan aksesibilitas fisik wilayah) maka akan dapat meningkatkan rata-rata 0,012 Kasus Gizi Buruk per 1000 penduduk dengan asumsi variabel lain tetap. Secara rata-rata setiap 1 $\mathrm{km}$ jalan berkualitas baik dan sedang adalah 4,95 km², sehingga daerah-daerah yang memiliki skala wilayah yang luas khususnya di Pulau Sumbawa memiliki tingkat layanan infrastruktur transportasi berkualitas baik yang rendah seperti di Kabupaten Sumbawa dengan rata-rata setiap $1 \mathrm{~km}$ jalan berkualitas baik dan sedang untuk wilayah seluas $14,95 \mathrm{~km}^{2}$.

Peningkatan rasio jumlah penduduk yang mendapat pelayanan setiap satu unit rumah sakit menunjukkan penurunan pelayanan fasilitas kesehatan. Rasio jumlah penduduk yang mendapat pelayanan setiap satu unit rumah sakit memiliki koefisien regresi dengan tanda positif. Hal ini menunjukkan jika terjadi penurunan pelayanan fasilitas kesehatan maka akan dapat menurunkan derajat kesehatan seperti peningkatan kasus gizi buruk di wilayah tersebut.

Studi Sultana dan Kiani (2011) menemukan bahwa ketersediaan infrastruktur (urban) berdampak nyata dan negatif terhadap status ketahanan pangan rumah tangga. Sedangkan Chizuni (1994) menemukan kebijakan pemerintah untuk mendorong produksi pangan di wilayah maka situasi kerawanan pangan dapat diperbaiki.

\section{SIMPULAN}

1) Kinerja ketahanan pangan di Provinsi NTB diukur dari : (a) Rata-rata nilai indeks ketersediaan pangan padi pada tahun 2012 adalah sebesar 2,91 yang bermakna bahwa ketersediaan pangan dari produksi padi adalah sebesar 2,91 dari kebutuhan pangan padi normatif dengan kecenderung semakin meningkat. (b) Nilai koefisien variasi (KV) harga pangan beras pada tahun 2012 adalah rata-rata sebesar 0.05 dengan kecenderungan nilai koefisien semakin rendah yang menunjukkan harga semakin stabil. (c) Persentase penduduk miskin adalah rata-rata $18.17 \%$ dengan kecenderung semakin menurun. (d) Rata-rata rasio kasus gizi buruk per 1000 penduduk adalah sebanyak 0,20 dengan kecenderung semakin menurun.

2) Faktor-faktor yang mempengaruhi kinerja ketahanan pangan Di Provinsi NTB adalah : (a) Peningkatan indeks ketersediaan pangan padi dipengaruhi oleh peningkatanpenguasaanlahan pertanian, produktivitas pangan, dan peningkatan aksesibilitas /infrastruktur transportasi yang memadai. (b) Penurunan Nilai koefisien variasi (KV) pangan beras dipengaruhi oleh tingkat ketersediaan beras dan peningkatan pelayanan lembaga disribusi pangan (koperasi). (c) Penurunan Persentase penduduk miskin dipengaruhi oleh ketersediaan layanan lembaga keuangan dan perbankan, peningkatan pendidikan masyarakat dan ketersediaan infrastruktur transportasi berkualitas. (d) Penurunan rasio kasus gizi buruk per 1000 penduduk dipengaruhi oleh tingkat produktivitas pangan, tingkat pelayanan infrastruktur berkualitas (akses fisik) dan tingkat pelayanan kesehatan penduduk.

\section{Rekomendasi}

Untuk meningkatkan ketahanan pangan tingkat wilayah di Provinsi NTB maka perlu upaya peningkatan produktivitas lahan pertanian, peningkatan akses lembaga keuangan, peningkatan peran koperasi dalam mendukung kegiatan usaha tani dan distribusi pangan, Pendidikan masyarakat serta pengembangan pelayanan kesehatan di Provinsi NTB. Untuk itu perlu dibuatkan Master plan/Road map/Rencana Aksi terkait peningkatan ketahanan pangan bukan hanya ditingkat Provinsi namun juga ditingkat kabupaten yang didukung oleh Peraturan Daerah/Peraturan Bupati. 


\section{DAFTAR PUSTAKA}

Adenew B, 2004. The Food Security Role of Agriculture in Ethiopia. Ejade electronic Journal of Agricultura dan Development Economics; Vol. 1, No. 1, 2004

Ariani, M., et al., 2007.Wilayah Rawan Pangan dan Gizi Kronis di Papua, Kalimantan Barat dan Jawa Timur. Pusat Analisis Sosial Ekonomi dan Kebijakan Pertanian-Departemen Pertanian. ISBN : 978-9793566-62-7.

BPS NTB, 2004-2013. Kabupaten dan Provinsi NTB Dalam Angka 2003-2012. BPS NTB, Mataram

Braun, V., J., McComb, J., B.K. F. Mensah, and R. P. Lorch. 1993. Urban Food Insecurity and Malnutrition in Developing Countries: Trends, Policies, and Research Implications. International Food Policy Research Institute, Washington, D.C.

Committee on World food security, 2012. Sosial Protection For Food Security The High Level Panel of Experts on food security and Nutrition. Help report4. Committee on World food security High Level Panel of Experts on food security dan Nutrition. Rome, 2012

FSVA NTB, 2010. Peta Ketahanan dan Kerentanan Pangan Nusa Tenggara Barat 2010. Pemerintah Provinsi Nusa Tenggara Barat, Dewan Ketahanan Pangan-Kementerian Pertanian, World Food Programme

FSVA, 2009. Peta ketahanan dan kerentanan pangan Indonesia. Dewan ketahanan Pangan Departemen Pertanian. World food programe (WFP). Jakarta

Herbel D., Crowley E; Haddad No, Lee M., 2012. Good Practices In Building Innovative Rural Institutions To Increase Food Security, FAO 2012

Hossain M, Naher F. and Shahabuddin Q, 2005. Food Security dan Nutrition in Bangladesh: Progress dan Determinants. electronic Journal of Agriculture and Development Economics; Vol. 2, No. 2, 2005

IFPRI, 2011. CGIAR Research Program 2-Policies, Institution, Dan Markets To Strengthen Food Security And Income For The Rural Poor-A revised proposal submitted to the CGIAR Consortium Board by the Internasional Food Policy Research Institute (IFPRI)-January 2011

Ikhsan, M. 2001. The Disagregation of Indonesian Poverty. PhD Dissertation. University of Illinois, Urbana-Champaign.

Irawan, B. 2004.Konversi lahan sawah di Jawa dan dampaknya terhadap produksi padi. Di dalam: Kasyrino F, Pasandaran E, Fagi A, editor. Ekonomi Padi dan Beras Indonesia. Badan Penelitian dan Pengembangan Pertanian, Jakarta.

Maxwell, D. G. 1996. Measuring Food Insecurity: The Frequency and Severity of Coping Strategies. The Frequency and Severity of Coping Strategies. Food Policy 21
Nazam M, 2011. Penyusunan Model Untuk Penetapan Luas Lahan Optimum Usaha Tani Padi Sawah Padawilayah Beriklim Kering Mendukung Kemandirian Pangan Berkelanjutan (Studi Kasus Provinsi Nusa Tenggara Barat). Disertasi Sekolah Pascasarjana Institut Pertanian Bogor. Bogor.

Nissanke M, 2011. Internasional Dan Institusional Traps In Sub-Saharan Africa Under Globalisation: A Comparative Perspective". Center for Economic Institusi Working Paper Series No. 2011-6. September 2011; Center for Economic Institution Working Paper Series

Nurmalina R. 2007. Model Neraca Ketersediaan Beras yang Berkelanjutan untuk Mendukung Ketahanan Pangan Nasional. Disertasi.Sekolah Pascasarjana Institut Pertanian Bogor. Bogor.

Nurmalina R. 2008. Analisis indeks dan status keberlanjutan sistem ketersediaan beras di beberapa wilayah Indonesia.Jurnal Agro Ekonomi. 26

Pemerintah Provinsi NTB. 2010. Rencana aksi daerah pangan dan gizi. Pemerintah provinsi NTB. Mataram

Purwantini, TB. et. Al. 2006. Analisis Ketahanan Pangan Regional Dan Tingkat Rumah Tangga (Studi Kasus di Provinsi Sulawesi Utara). Pusat Analisis Sosial Ekonomi dan Kebijakan Pertanian.

Rusastra IW., Napitupulu TA., dan Bourgeois R., 2008. The Impact Of Support For Imports On Food Security In Indonesia. CAPSA Working Paper No. 101. Economic and Sosial Commission For Asia Dan The Pacific. United Nations New York.

Saliem,HP.,et. Al. 2006.Diversifikasi Usaha Rumah Tangga Dalam Mendukung Ketahanan Pangan dan Penanggulangan Kemiskinan Diindonesia.Pusat Analisis Sosial Ekonomi dan Kebijakan Pertanian Departemen Pertanian.

Socha T., Zahaf M., Chambers L, Abraham R., Fiddler T., 2012. Food Security in a Northern First Nations Community: An Exploratory Study on Food Availability dan Accessibility. Journal of Aboriginal Health, March 2012

Sultana A, and Kiani A, 2011. Determinants of Food security at household level in Pakistan. African Journal of Business Management Vol. 5(34), 28 December, 2011

Suryana, A., 2003. Kapita Selekta : Evolusi Pemikiran Kebijakan Ketahanan Pangan,Edisi 2003/2004, BPFE-YOGYAKARTA, Yogyakarta.

Undang-Undang Nomor 18 Tahun 2012 tentang Pangan. Setneg RI. Jakarta

Yudhoyono, S.B. dan Harniati. 2004. Pengurangan Kemiskinan di Indonesia: Mengapa Tidak Cukup dengan Memacu Pertumbuhan Ekonomi? Brighten Press, Bogor. 